\title{
ODPOWIEDZIALNOŚĆ PRACODAWCY Z TYTUŁU WADLIWEGO WYPOWIEDZENIA LUB ROZWIAZZANIA UMOWY O PRACĘ ZAWARTEJ NA CZAS OKREŚLONY- UWAGI DE LEGE LATA I DE LEGE FERENDA
}

\begin{abstract}
The employer's liability on account of unjustified or unlawful termination of a contract of employment for a fixed term - conclusions de lege lata and de lege ferenda
\end{abstract}

The aim of this article is to present comments and suggestions regarding currently existing solutions in terms of incorrectness of termination or dissolution of a fixed-term employment contract. Due to recent legislative changes, the issue of possibility to terminate or dissolve fixed-term employment contracts became actual more than ever before.

In this article there are raised concerns regarding the admissibility of analysis of justification of termination of fixed-term employment contracts, claims of employees' granted them on the basis of incorrect termination of a fixed-term employment contract, including restitution claim with a special attention paid to the legal status of employees encompassed with special protection of employment status.

Further subjected to the analysis were the rights of employee that arise from unlawful termination of employment contract without a notice by employer and legal character of compensation for incorrect termination or dissolution of a fixed-term employment contract.

Mentioned considerations were supported by the analysis of judicature and state of doctrine with particular emphasis on suggested recommendations on changing currently applicable solutions.

In the summary, Author presented clear vision of direction, which should be followed by the legislator in order to secure coherence of legal system and improvement of position currently occupied by subjects particularly affected by issues connected with adopted regulations in terms of incorrectness of termination or dissolution of a fixed-term employment contract.

Słowa kluczowe: wypowiedzenie umowy, rozwiązanie umowy, umowa na czas określony, roszczenia, charakter prawny odszkodowania, postulaty zmian

Key words: termination, dissolution, fixed-term employment contract, claims, legal character of compensation, recommendations for future regulations 


\section{Uwagi wprowadzające}

Zagadnienia związane z odpowiedzialnością pracodawcy z tytułu ${ }^{1}$ wadliwego rozwiązania za wypowiedzeniem lub bez wypowiedzenia umowy o pracę, pomimo upływu lat, niezmiennie wywołują wiele kontrowersji w orzecznictwie i doktrynie prawa pracy ${ }^{2}$. Niesłabnąca zwłaszcza jest dyskusja na temat charakteru prawnego i podstaw tej odpowiedzialności, a także prawnej możliwości sięgania do przepisów Kodeksu cywilnego w zakresie uregulowania odpowiedzialności odszkodowawczej pracodawcy.

Dynamika ostatnich zmian legislacyjnych w zakresie zatrudnienia na czas określony, w mojej ocenie, uzasadnia zrewidowanie zakresu ochrony prawnej pracownika w związku z wadliwym wypowiedzeniem lub rozwiązaniem umowy o pracę zawartej na czas określony. Ten typ umowy charakteryzuje się obecnie łatwością wypowiedzenia i stosunkowo mało dotkliwymi sankcjami za wadliwe wypowiedzenie czy rozwiązanie bez wypowiedzenia. W konsekwencji prowadzi to do istotnego ograniczenia stabilności stosunku pracy nawiązanego na jej podstawie. Jak wiadomo, czynności pracodawcy w omawianym zakresie (także te sprzeczne z prawem) są skuteczne, a więc naruszenie prawa nie powoduje nieważności tych czynności, lecz wyłącznie możliwość dochodzenia przez pracownika roszczeń przewidzianych w kodeksie pracy.

\section{„Bezzasadność" wypowiedzenia umowy o pracę zawartej na czas określony}

Wskutek wejścia w życie ustawy z dnia 25 czerwca 2015 r. o zmianie ustawy Kodeks pracy oraz niektórych innych ustaw ${ }^{3}$ wprowadzono liczne zmiany w zakresie samego zawierania umów na czas określony, jednocześnie pozostawiając kwestie roszczeń związanych $z$ ich wadliwym wypowiedzeniem lub rozwiązaniem przez pracodawcę bez wypowiedzenia w niezmienionym kształcie. W świetle dokonanych zmian należy na nowo poddać dyskusji kwestię zarówno obowiązku uzasadniania przez pracodawcę

1 Zagadnienie odpowiedzialności pracodawcy z tytułu wadliwego wypowiedzenia lub rozwiązania umowy o pracę zawartej na czas określony zostało ograniczone do problematyki wynikającej wyłącznie z przepisów Kodeksu pracy.

2 B. Cudowski, Roszczenia z tytułu bezprawnego wypowiedzenia umowy o pracę na czas określony, Praca i Zabezpieczenie Społeczne 2011, 6, s. 18-25, Ł. Pisarczyk, Odszkodowanie z tytułu wadliwego wypowiedzenia lub rozwiazania umowy o prace przez pracodawcę, Praca i Zabezpieczenie Społeczne 2002, 8, s. 18-26, A. Sobczyk, Niewłaściwe ustanie stosunku pracy, Praca i Zabezpieczenie Społeczne 2014, 1, s. 12. W. Sanetra, Odszkodowanie „cywilne” za wadliwe rozwiązanie umowy o prace - czyli o pogladach nadal godnych uwagi, w: Z. Niedbała, M. Skąpski (red.), Problemy zatrudnienia we współczesnym ustroju pracy. Ksiega jubileuszowa na 55-lecie pracy naukowej i dydaktycznej Profesora Włodzimierza Piotrowskiego, Poznań 2008; M. Gersdorf, Otwarte drzwi dla odpowiedzialności cywilnej pracodawcy za wadliwe zwolnienie pracownika, Praca i Zabezpieczenie Społeczne 2008, 1, s. 2.; A. Sobczyk, Wolność pracy i władza, Warszawa 2015, s. 167-170.

3 Dz. U. z 2015 r., poz. 1220, która weszła w życie 22 lutego 2016 r. 
wypowiedzenia umowy o pracę na czas określony, jak również sposobu ukształtowania roszczeń pracowniczych z tego tytułu.

W obecnie obowiązującym stanie prawnym odpadła - przynajmniej teoretyczna możliwość wpływu pracownika na „wypowiadalność" umowy o pracę zawieranej na czas określony. Na gruncie przepisów Kodeksu pracy, po zmianie stanu prawnego, każda umowa o pracę na czas określony, a nie tylko taka, w której przy dłuższym niż 6-miesięczny okresie obowiązywania strony przewidziały taką możliwość, stała się w pełni wypowiadalną. Zasada ta dotyczy przede wszystkim takich „szczególnych” rodzajów umów na czas określony, jak wymienione w art. $25^{1} \S 4 \mathrm{kp}$ umowy o pracę zawarte na czas określony w celu zastępstwa pracownika w czasie jego usprawiedliwionej nieobecności w pracy, jak również w celu wykonywania pracy o charakterze dorywczym lub sezonowym.

Powyższe, w połączeniu z brakiem ustawowej podstawy prawnej zobowiązującej pracodawcę do wskazywania pracownikowi na piśmie przyczyn wypowiedzenia takiej umowy, wywołuje poważne wątpliwości co do poprawności legislacyjnej tej regulacji z punktu widzenia funkcji, jakie ma ona spełniać. Nie są one w zasadzie niczym nowym, gdyż nawet wówczas, gdy Trybunał Konstytucyjny niejako przesądzająco orzekł o zgodności z konstytucją art. $30 \$ 4 \mathrm{kp}$ w zakresie, w jakim pomija potrzebę wskazania przyczyny uzasadniającej wypowiedzenie w oświadczeniu pracodawcy o wypowiedzeniu umowy o pracę zawartej na czas określony ${ }^{4}$, w nauce prawa pracy nie ustała dyskusja ten temat ${ }^{5}$. Trybunał Konstytucyjny w zacytowanym powyżej wyroku przyznał, iż sąd, na wniosek eks-pracownika, może poddać kontroli wypowiedzenie umowy o pracę zawartej na czas oznaczony, również pod kątem ewentualnego naruszenia społeczno-gospodarczego przeznaczenia prawa lub zasad współżycia społecznego (art. $8 \mathrm{kp}$ ) bądź zaistnienia niedozwolonego przez prawo zróżnicowania bądź dyskryminacji pracownika w sytuacji określonej przez art. $11^{3}$ oraz art. $18^{3 a} \mathrm{kp}$, wykraczających poza sam fakt wypowiedzenia umowy o pracę na czas oznaczony.

W mojej ocenie, pomimo bezdyskusyjnej słuszności stanowiska Trybunału Konstytucyjnego, tak zakreślony obszar kontroli sądowej zasadności wypowiedzenia umowy o pracę zawartej na czas określony nie wydaje się wystarczający. W obecnym stanie prawnym, w którym wprowadzono co do zasady pełną wypowiadalność umów na czas określony, zasadne jest ponowne przeanalizowanie tej kwestii z uwagi na takie wartości konstytucyjne, jak chociażby zasada równości i niedyskryminacji (art. 32 konstytucji) czy też sprawiedliwości społecznej (art. 2 konstytucji). Nie wydaje się, jakoby istniały usprawiedliwione społecznie kryteria przemawiające za różnicowaniem sytuacji prawnej pracowników zatrudnionych na podstawie umowy o pracę zawartej na czas określony i nieokreślony.

${ }_{4}$ Wyrok Trybunału Konstytucyjnego z dnia 2 grudnia 2008 r. , P 48/07 OTK-A 2008, nr 10, poz. 173.

5 Zob. zdanie odrębne Sędziego Trybunału Konstytucyjnego Teresy Liszcz do wyroku Trybunału Konstytucyjnego z dnia 2 grudnia 2008 r., sygn. akt P 48/07 OTK-A 2008/10/173. 


\section{Roszczenia z tytułu wadliwego wypowiedzenia umowy o pracę zawartej na czas określony}

Roszczenia, jakie przysługują pracownikowi w związku z naruszeniem przez pracodawcę przepisów o wypowiadaniu umów zawartych na czas określony, zostały uregulowane $\mathrm{w}$ art. $50 \S 3-\S 5 \mathrm{kp}$.

Biorąc pod uwagę obowiązującą obecnie regulację w zakresie umów na czas określony, można mieć uzasadnione wątpliwości co do praktycznego znaczenia art. $50 \$ 3-\S 5 \mathrm{kp}$, a co za tym idzie efektywnej realizacji funkcji ochronnej prawa pracy. Zgodnie z tym przepisem, jeżeli wypowiedzenie umowy o pracę zawartej na czas określony nastąpiło z naruszeniem przepisów o wypowiadaniu takiej umowy, pracownikowi przysługuje wyłącznie odszkodowanie.

Dotychczasowe wypowiedzi doktryny i orzecznictwa sądowego, zmierzające do wyjaśnienia zakresu przedmiotowego przesłanki „z naruszeniem przepisów o wypowiadaniu tych umów”, koncentrowały się wokół tego, czy wypowiedzenie umowy o pracę zawartej na czas określony z naruszeniem nieobowiązującego już art. $33 \mathrm{kp}$ mieściło się w pojęciu naruszenia przepisów o wypowiadaniu umów na czas określony. Wątpliwości pojawiały się zwłaszcza w sytuacji, gdy pracodawca wypowiedział umowę o pracę zawartą na czas określony, w której strony nie przewidziały możliwości jej wypowiedzenia. Doktryna prawa pracy była w tym temacie podzielona ${ }^{6}$. Sąd Najwyższy skłaniał się w swych orzeczeniach, choć niekonsekwentnie, w kierunku uznania, iż wypowiedzenie umowy o pracę zawartej na czas określony dokonane $\mathrm{z}$ naruszeniem art. $33 \mathrm{kp}$ jako dokonane $\mathrm{z}$ naruszeniem przepisów o wypowiadaniu tych umów podlega regulacji z art. $50 \$ 3-\$ 5 \mathrm{kp}$.

W obecnie obowiązującym stanie prawnym, kiedy to ustawodawca nie uzależnia już możliwości wypowiedzenia umowy o pracę od woli stron i długości okresu, na jaki została zawarta, a także wprowadził mechanizm zmierzający do wyeliminowania z obrotu umów wieloletnich ${ }^{7}$, uprawniony jest wniosek, iż praktyczne znaczenie roszczenia odszkodowawczego, o którym mowa w art. $50 \$ 3 \mathrm{kp}$, zostało zmarginalizowane. Wydaje się bowiem, iż w obecnym stanie prawnym na gruncie Kodeksu pracy naruszenie przez pracodawcę „przepisów o wypowiadaniu tych umów” ogranicza w istocie uprawnienia pracownika tylko do stawiania zarzutu formalnego w postaci formy pisemnej dla oświadczenia o wypowiedzeniu (art. $30 \$ 4 \mathrm{kp}$ ). Nie twierdzę, bynajmniej, iż pracownicy zatrudnieni na podstawie umów o pracę na czas określony, którym pracodawca wypowiedział we właściwej formie umowę o pracę, są pozbawieni jakiejkolwiek ochrony prawnej. Twierdzę jedynie, iż ich ochrona $z$ tytułu naruszenia przez pracodawcę przepisów o wypowiadaniu umów o pracę na czas określony praktycznie nie istnieje przy dochowaniu przez pracodawcę wymogów pisemności oświadczenia o rozwiązaniu umowy.

6 Poglądy doktryny prawa pracy dotyczące tego zagadnienia obszernie przedstawia B. Cudowski, Roszczenia z tytułu bezprawnego..., s. 19.

7 Poprzez wprowadzenie ograniczeń wynikających z art. $25^{1} \mathrm{kp}$. 
Co więcej, pomimo braku wymogu uzasadniania wypowiedzenia umowy zawartej na czas określony Sąd Najwyższy w wielu przypadkach opowiadał się za dopuszczalnością badania przez sąd powszechny, czy w konkretnej sytuacji faktycznej nie mamy do czynienia $\mathrm{z}$ naruszeniem art. $8 \mathrm{kp}$. Innymi słowy, możliwe jest stwierdzenie, że wykonanie przez pracodawcę prawa podmiotowego (wypowiedzenie umowy) stanowiło jego nadużycie ze względu na sprzeczność z zasadami współżycia społecznego lub społeczno-gospodarczym przeznaczeniem prawa (art. $8 \mathrm{kp})^{8}$. Sąd Najwyższy w sposób utrwalony orzekał również, iż brak jest także podstaw, by odmówić sądowi pracy uprawnienia do badania przyczyny wypowiedzenia umowy o pracę zawartej na czas określony w sytuacji, gdy chodzi o stwierdzenie, czy ta przyczyna nie miała charakteru dyskryminacyjnego. $\mathrm{Z}$ art. $18^{3 \mathrm{~b}}$ $\$ 1$ pkt $1 \mathrm{kp}$ wynika bowiem, że naruszeniem zasady równego traktowania w zatrudnieniu jest różnicowanie sytuacji pracownika $\mathrm{z}$ jednej lub kilku przyczyn określonych $\mathrm{w}$ art. $18^{3 a} \S 1 \mathrm{kp}$, którego skutkiem jest rozwiązanie stosunku pracy, bez względu na to, czy został on nawiązany na podstawie umowy o pracę zawartej na czas nieokreślony, czy też umowy terminowej. Pracownik zatrudniony na czas określony nie może być więc pozbawiony ochrony przed rozwiązaniem umowy o pracę z przyczyn dyskryminacyjnych, a to oznacza, że sąd pracy jest uprawniony do oceny, czy przyczyny wypowiedzenia umowy o pracę nie miały takiego charakteru.

Z faktu, że pracodawca nie ma obowiązku podawania pracownikowi na piśmie przyczyn uzasadniających wypowiedzenie terminowej umowy o pracę, nie wynika bowiem, że przyczyny takie obiektywnie nie istnieją. Przeciwnie, każda decyzja o wcześniejszym rozwiązaniu z pracownikiem stosunku pracy jest uwarunkowana jakimś okolicznościami znanymi pracodawcy, których udowodnienia może żądać sąd w sytuacji, gdy powód uprawdopodobni, że wypowiedzenie umowy o pracę zawartej na czas określony nastąpiło ze względu na kryteria dyskryminacyjne ${ }^{9}$.

Przytoczonym powyżej wypowiedziom Sądu Najwyższego trudno odmówić słuszności. Nie zmienia to jednak faktu, iż nie mają one wpływu na ocenę skuteczności ochrony pracownika przed arbitralnym i dowolnym wypowiedzeniem umowy o pracę zawartej na czas określony. Co więcej, aby pracownik mógł skutecznie w postępowaniu sądowym wykorzystać wskazane zarzuty, musiałby przynajmniej pozyskać wiedzę o tym, dlaczego został zwolniony, co w wielu przypadkach może być trudne czy wręcz niemożliwe.

8 Wykładnia ta jest utrwalona w orzecznictwie. W szczególności w wyroku z 19 lipca 1984 r., I PRN 98/84 (OSPiKA 1985 nr 12, poz. 237, z glosą T. Zielińskiego) Sąd Najwyższy przyjął, że art. 8 kp może mieć zastosowanie przy naruszającym zasady współżycia społecznego wypowiedzeniu terminowych umów o pracę, do których art. $45 \mathrm{kp}$ nie ma zastosowania. Podobne stanowisko zaprezentowane zostało także w wyrokach z dnia 8 grudnia 2005 r., I PK 103/05 (OSNP 2006 nr 21-22, poz. 321) i z dnia 5 grudnia 2007 r., II PK 122/07 (Monitor Prawniczy 2009, nr 12), w których Sąd Najwyższy stwierdził, między innymi, że sąd pracy może oceniać wypowiedzenie umowy o pracę zawartej na okres próbny i na czas określony co do jego zgodności z zasadami współżycia społecznego lub społeczno-gospodarczym przeznaczeniem prawa (art. $8 \mathrm{kp}$ ). Z późniejszych orzeczeń należy wskazać na wyrok Sądu Najwyższego z dnia 22 maja 2012 r. II PK 245/11, OSNP 2013/7-8/82, w którym sąd przywołuje wiele wcześniejszych, spójnych $\mathrm{z}$ zaprezentowanym stanowiskiem wypowiedzi judykatury.

9 Wyrok Sądu Najwyższego z dnia 22 maja 2012 r. II PK 245/11, OSNP 2013/7-8/82. 
Kolejne trudności dla praktycznej wzruszalności wypowiedzenia umowy o pracę zawartej na czas określony pojawią się w zakresie dowodowym. O ile w odniesieniu do zarzutu dyskryminacji wystarczające jest uprawdopodobnienie, iż w stosunku do pracownika pracodawca naruszył przepisy dotyczące równego traktowania w zatrudnieniu, o tyle w przypadku naruszenia art. $8 \mathrm{kp}$ sytuacja procesowa pracownika jest znacznie bardziej skomplikowana.

Co więcej, jak się wydaje tylko odnośnie do zarzutu dyskryminacji nie ma prawnych wątpliwości co do tego, iż naruszenie przepisów o równym traktowaniu mieści się w zakresie przedmiotowym „naruszenia przepisów o wypowiadaniu umów”, warunkujących ochronę prawną z tytułu wadliwego wypowiedzenia umowy o pracę, o której mowa w art. $50 \mathrm{kp}$. Powyższe stwierdzenie uzasadnia treść art. $18^{3 \mathrm{~b}} \S 1$, zgodnie z którym za naruszenie zasady równego traktowania $\mathrm{w}$ zatrudnieniu uważa się między innymi różnicowanie przez pracodawcę sytuacji pracownika $\mathrm{z}$ jednej lub kilku przyczyn określonych $\mathrm{w}$ art. $18^{3 \mathrm{a}} \S 1$, którego skutkiem jest w szczególności rozwiązanie stosunku pracy.

Jeżeli zaś chodzi o zarzut naruszenia przez pracodawcę art. $8 \mathrm{kp}$, można mieć poważne wątpliwości co do tego, czy wypowiedzenie dokonane w sposób sprzeczny ze społeczno-gospodarczym przeznaczeniem prawa pracodawcy do wypowiedzenia umowy o pracę zawartej na czas określony lub sprzeczne z zasadami współżycia społecznego mieści się $\mathrm{w}$ zakresie przedmiotowym wypowiedzenia „dokonanego $\mathrm{z}$ naruszeniem przepisów o wypowiadaniu tych umów". W mojej ocenie jest to inny typ naruszenia prawa, który nie podlega ochronie na podstawie art. $50 \$ 3 \mathrm{kp}$. Klauzula generalna, zawarta w art. $8 \mathrm{kp}$, zwana niekiedy „,klauzulą nadużycia prawa”, dotyczy bowiem „,nadużycia”, a nie „naruszenia” prawa. Oznacza to, iż skoro hipotezą normy art. 8 kp objęte są przypadki nadużycia, a nie obrazy prawa, to regulacja ta nie dotyczy sytuacji, gdy określony podmiot narusza przepisy prawa materialnego. Konstrukcja ta obejmuje właśnie te przypadki, w których zachowanie określonego podmiotu spełnia formalnie wszystkie wymagania przewidziane przepisem prawa, natomiast $\mathrm{z}$ innych - pozaprawnych - względów (np. społecznych czy moralnych) zachowanie to nie zasługuje na ochronę prawną. Przepis ten nie przyznaje żadnych praw podmiotowych, a jedynie upoważnia sąd do oceny, w jakim zakresie, w konkretnym stanie faktycznym, działanie lub zaniechanie uprawnionego nie jest uważane za wykonywanie jego prawa i nie korzysta $\mathrm{z}$ ochrony prawnej.

Biorąc pod uwagę powyższe, wyrażam pogląd, zgodnie z którym w typowych sytuacjach, w odniesieniu do „zwykłych” pracowników praktyczne zastosowanie art. $50 \$ 3 \mathrm{kp}$ może zostać zmarginalizowanie. Inaczej rzecz ta ma się w odniesieniu do pracowników korzystających z ochrony szczególnej, o czym będzie mowa w dalszej części. 


\section{Roszczenie restytucyjne w przypadku wypowiedzenia umowy o pracę zawartej na czas określony}

Od początku obowiązywania Kodeksu $\operatorname{pracy}^{10}$ w przypadku wadliwego wypowiedzenia umowy o pracę silnie akcentowany był prymat roszczenia restytucyjnego nad odszkodowawczym. W pierwotnym brzmieniu kodeksu w art. 45 roszczenie restytucyjne było jedynym, jakie ustawodawca przewidywał z tytułu wadliwego wypowiedzenia umowy o pracę zawartej na czas nieokreślony. Warto jednak nadmienić, iż w pierwotnym brzmieniu Kodeks pracy w ogóle nie przywidywał prawnej możliwości wypowiedzenia umowy o pracę zawartej na czas określony. Wypowiadalne były wyłącznie: umowa o pracę na okres próbny, na okres wstępny ${ }^{11}$ i na czas nieokreślony. Co za tym idzie, każde wypowiedzenie umowy o pracę na czas określony było dokonywane z naruszeniem przepisów o wypowiadaniu tych umów.

Znamienne jest to, iż nawet w poprzednim ustroju społeczno-gospodarczym w przypadku wadliwego wypowiedzenia umowy o pracę zawartej na czas określony przewidziane było wyłącznie odszkodowanie (art. $50 \$ 3 \mathrm{kp}$ ). Wysokość tego odszkodowania, podobnie jak obecnie, limitowana była do wysokości wynagrodzenia za czas, do którego upływu umowa miała trwać, jednak nie więcej niż na 3 miesiące. Wyjątkowo w razie wypowiedzenia umowy o pracę pracownicy w okresie ciąży lub urlopu macierzyńskiego znajdowały zastosowanie przepisy art. $45 \mathrm{w}$ związku $\mathrm{z}$ art. $177 \mathrm{kp}$. Jak widać, od samego początku ustawodawca w przypadku wadliwego wypowiedzenia umowy o pracę zawartej na czas określony przewidywał odmienne ukształtowanie zakresu ochrony ze względu na szczególny status rodzinny. $Z$ biegiem lat katalog podmiotów podlegających wyłączeniu $\mathrm{z}$ tytułu art. $50 \$ 5 \mathrm{kp}$ był rozbudowywany, co było związane $\mathrm{z}$ dynamicznym procesem przemian ustawodawstwa pracy dotyczącego szeroko rozumianej ochrony rodzicielstwa.

W obecnie obowiązującym stanie prawnym zasada wyboru roszczenia restytucyjnego lub odszkodowania znajduje zastosowanie w odniesieniu do wypowiedzenia umowy o pracę zawartej na czas określony pracownicy w okresie ciąży lub urlopu macierzyńskiego, pracownika - ojca wychowującego dziecko w okresie korzystania z urlopu macierzyńskiego, a także pracownika w okresie korzystania z ochrony stosunku pracy na podstawie przepisów ustawy o związkach zawodowych - art. $50 \$ 5 \mathrm{kp}$. Odpowiednie

10 Ustawa z dnia 26 czerwca 1974 r. Dz. U., Nr 24, poz. 141.

11 Art. 28. kp przewidywał, iż pracownika podejmującego zatrudnienie po raz pierwszy oraz pracownika, który w żadnym zakładzie pracy nie przepracował co najmniej roku, uspołeczniony zakład pracy może zatrudnić na podstawie umowy o pracę na czas nieokreślony tylko po uprzednim zatrudnieniu go na okres próbny, a następnie na okres wstępny - łącznie w wymiarze roku. Z pracownikiem, o którym mowa powyżej, pozostającym w zatrudnieniu w tym samym zakładzie pracy po upływie okresu trwania umowy o pracę na czas określony lub na czas wykonania określonej pracy, jeżeli okres ten trwał krócej niż rok, zawiera się umowę o pracę na okres wstępny, uzupełniający okres zatrudnienia do roku. Jeżeli było to uzasadnione dobrymi wynikami pracy pracownika, kierownik zakładu pracy z własnej inicjatywy lub na wniosek rady zakładowej mógł skrócić okres wstępny, nie więcej jednak niż do 3 miesięcy. Art. 28 został skreślony przez art. 1 pkt 5 ustawy z dnia 7 kwietnia 1989 r. (Dz. U. z 1989 r., Nr 20, poz. 107) zmieniającej Kodeks pracy z dniem 1 maja 1989 r. 
stosowanie art. $50 \$ 5 \mathrm{kp}$ przewidują również inne jeszcze przepisy zaliczane do kategorii ochrony rodzicielstwa, takie jak regulacje dotyczące urlopu rodzicielskiego, urlopu ojcowskiego czy wreszcie urlopu na warunkach urlopu macierzyńskiego. O ochronie w przeważającej większości sytuacji decyduje więc wzgląd na różne aspekty ochrony życia rodzinnego stanowiącego konstytucyjną wartość (art. 18 konstytucji).

Godzi się zwrócić uwagę, iż katalog osób szczególnie chronionych zatrudnionych na podstawie umów o pracę na czas określony, które ustawodawca nakazuje traktować na równi z pracownikami zatrudnionymi na czas nieokreślony, został poszerzony o pracownika w okresie korzystania z ochrony stosunku pracy na podstawie przepisów ustawy o związkach zawodowych.

Zmiana ta została dokonana ustawą z dnia 26 maja 2011 r. o zmianie ustawy Kodeks pracy $^{12}$. Miała ona na celu wykonanie wyroku Trybunału Konstytucyjnego z dnia 12 lipca $2010 \mathrm{r}^{13}$, w którym trybunał przesądził o potrzebie przyznania restytucyjnej ochrony trwałości zatrudnienia działaczom związkowym zatrudnionym na czas oznaczony, co w ocenie trybunału jest strukturalnie związane $\mathrm{z}$ art. $50 \$ 3 \mathrm{kp} \mathrm{i} \mathrm{z} \mathrm{art.} 32$ ust. 1 pkt 1 oraz ust. 8 ustawy o związkach zawodowych, natomiast aksjologicznie, na szczeblu konstytucyjnym - zakotwiczone jest w art. 12 i art. 59 konstytucji.

Wyrok powyższy dotyczył tylko i wyłącznie działaczy związkowych podlegających ochronie na podstawie art. 32 ust. 1 pkt 1 i ust. 8 ustawy o związkach zawodowych. Ochronę tej grupy podmiotów (przez dopuszczenie żądania przywrócenia do pracy) zdaniem Trybunału Konstytucyjnego uzasadnia wartość konstytucyjna, jaką jest wolność zrzeszania się.

Trybunał Konstytucyjny uznał, że niezgodne z konstytucją jest ograniczenie zakresu roszczeń przysługujących pracownikowi (działaczowi związkowemu) zatrudnionemu na podstawie umowy na czas określony jedynie do odszkodowania (z pominięciem roszczenia o przywrócenie do pracy) w przypadku, gdy umowę o pracę wypowiedziano $\mathrm{z}$ naruszeniem art. 32 ust. 1 pkt 1 i ust. 8 ustawy o związkach zawodowych. Intencją trybunału, jak to sam przyznał, nie było rozszerzenie wyjątku przewidzianego w art. 50 $\S 5 \mathrm{kp}$ na wszystkie pozostałe wypadki ustawowego ograniczenia restytucyjnych postaci ochrony trwałości stosunku pracy. Stąd też, jak się wydaje, jako otwartą do dyskusji pozostawiono kwestię adekwatności ograniczenia i potrzeby ochrony trwałości stosunku pracy pozostałych grup pracowników szczególnie chronionych z punktu widzenia wartości konstytucyjnych.

Wywodom trybunału, co do zasady, nie można odmówić słuszności. W uzasadnieniu wyroku trybunału można jednak odnaleźć argumenty, które z powodzeniem mogłyby znaleźć zastosowanie do innych kategorii pracowników objętych ochroną szczególną, a niewymienionych $\mathrm{w}$ art. $50 \$ 5 \mathrm{kp}$. Biorąc pod uwagę spójność regulacji ochrony trwałości stosunku pracy pracowników zatrudnionych na podstawie umów na czas określony, pojawiają się istotne wątpliwości co do zgodności z konstytucją regulacji

12 Dz. U., Nr 144, poz. 855.

13 Wyrok Trybunału Konstytucyjnego z dnia 12 lipca 2010 r. P 4/10 OTK-A 2010 /6/58. 
zawartej w art. $50 \$ 5 \mathrm{kp} \mathrm{w}$ zakresie, w jakim pomija ona inne kategorie pracowników szczególnie chronionych. Mam tu zwłaszcza na myśli, choć nie wyłącznie, tych pracowników, których stabilność zatrudnienia może zostać narażona właśnie z uwagi na pełnione przez nich funkcje społeczne na rzecz wspólnoty zakładu pracy - tak jak to ma miejsce chociażby w przypadku społecznych inspektorów pracy czy też członków rad pracowników. Różnicowanie sytuacji prawnej pracowników szczególnie chronionych ze względu na pełnione funkcje i przyznanie prymatu wyłącznie tym pracownikom, którzy korzystają z ochrony na podstawie przepisów ustawy o związkach zawodowych, w mojej ocenie powinno mieć szczególnie silnie społeczne usprawiedliwienie. Wybiórcze potraktowanie kategorii pracowników podlegających szczególnej ochronie trwałości stosunku pracy w odniesieniu do wypowiedzenia umowy zawartej na czas określony powinno być ponownie przedyskutowane i przeanalizowane. Dodanie do katalogu szczególnie chronionego działacza związkowego, a przez to wykroczenie ustawodawcy poza krąg podmiotów korzystających z szeroko rozumianej ochrony rodzicielstwa, albo nie powinno mieć miejsca w ogóle, albo powinno być pierwszym krokiem do poszerzenia wyjątków $\mathrm{z}$ art. $50 \$ 5 \mathrm{kp}$.

W alternatywie do poszerzenia zakresu podmiotowego zastosowania katalogu określonego w art. $50 \$ 5$ kp (które może być uzasadnione jedyne przez pryzmat braku konsekwencji ustawodawcy w traktowaniu podmiotów szczególnie chronionych) w sposób analogiczny do regulacji z art. $45 \$ 3 \mathrm{kp}$ warte rozważenia wydaje się następujące rozwiązanie: wprowadzenie powszechnego wymogu pisemnego uzasadniania wypowiedzenia umowy na czas określony w połączeniu $\mathrm{z}$ całkowitym odejściem od roszczenia o przywrócenie do pracy na poprzednich warunkach za cenę odszkodowania w wysokości wynagrodzenia za czas, do którego upływu umowa miała trwać. W odniesieniu do pracowników korzystających z ochrony szczególnej mógłby to być okres dłuższy, np. dwukrotnie, czy też odpowiadający temu, na który pracownikowi z mocy szczególnych przepisów przysługuje ochrona zatrudnienia. Nie miałoby to charakteru fikcyjnego przedłużenia trwania stosunku pracy, a jedynie ustawowe podwyższenie swego rodzaju kary cywilnej dla pracodawcy w przypadku ustalenia przez sąd, iż wypowiedzenie nastąpiło właśnie z tych przyczyn, z których przyznano pracownikowi ochronę.

Wydaje się, iż mogłoby to w istotny sposób uprościć i ujednolicić praktykę orzeczniczą bez umniejszenia ochrony zwalnianego pracownika. W obecnym stanie prawnym, nawet gdy ustawodawca przyznaje pewnej grupie pracowników zatrudnionych na czas określony możliwość orzeczenia przez sąd pracy przywrócenia do pracy na poprzednich warunkach, w każdym przypadku jest to uzależnione od tego, czy sąd niejako „zdąży z wyrokiem”, zanim nie upłynie jeszcze termin, do końca którego umowa miała trwać. W połączeniu z przyjętymi ograniczeniami dla prawnej możliwości zawierania wieloletnich umów o pracę może być to obecnie znacznie utrudnione.

Co więcej, konstrukcja ustawowa polegająca na przywracaniu do pracy pracownika szczególnie chronionego, któremu pracodawca wypowiedział umowę o pracę na czas określony, do którego z mocy odwołania z art. $50 \$ 5$ stosujemy art. $45 \$ 3$ bez badania celu, w jakim umowa została w ogóle zawarta, i bez sposobności oceny merytorycznej 
możliwości zrealizowania tego celu wskutek przywrócenia do pracy, polega wyłącznie na stworzeniu zwolnionemu pracownikowi możliwości otrzymania wynagrodzenia za cały okres pozostawania bez pracy. Jak wiadomo, w świetle obowiązujących przepisów wyłącznie likwidacja pracodawcy daje sądowi możliwość nieprzywracania takiego pracownika do pracy. Sytuacja ta wydaje się szczególnie kuriozalna wówczas, gdy z zebranego w sprawie materiału wynika, iż decyzja pracodawcy jest merytorycznie uzasadniona, a jedynie ze względów formalnych (brak zgody właściwego organu związkowego) pracodawca naruszył przepisy o wypowiadaniu umowy. Niejednokrotnie zgłoszenie przez pracownika gotowości podjęcia pracy i jej podjęcie jest motywowane wyłącznie otrzymaniem owego wynagrodzenia za cały okres trwania procesu sądowego bez rzeczywistego zamiaru efektywnego świadczenia pracy do końca przewidzianego okresu obowiązywania umowy. W przypadku umów na czas określony ingerencja ustawodawcy wydaje się tu niezbędna, np. poprzez uzależnienie przyznania odszkodowania za cały okres pozostawania bez pracy od efektywnego przepracowania przez pracownika pewnego określonego minimum czasu po przywróceniu. Jako rażąco niesprawiedliwa jawi się aktualna konstrukcja prawna, zwłaszcza po spojrzeniu na nią przez pryzmat braku jakiejkolwiek ochrony prawnej dla pracodawcy, któremu to pracownik wypowiedział umowę o pracę przykładowo zaraz po przywróceniu do pracy i wypłaceniu wynagrodzenia za cały okres pozostawania bez pracy.

\section{Uprawnienia pracownika w razie niezgodnego z prawem rozwiązania przez pracodawcę umowy o pracę bez wypowiedzenia}

Uprawnienia pracownika $\mathrm{w}$ razie niezgodnego z prawem rozwiązania przez pracodawcę umowy o pracę bez wypowiedzenia w niemal niezmienionym kształcie przetrwały przez ponad 40 lat. Jeżeli chodzi o uprawnienia pracownika zatrudnionego na podstawie umowy o pracę zawartej na czas określony, która została przez pracodawcę rozwiązana z naruszeniem przepisów o rozwiązywaniu umów w tym trybie, to zgodnie z art. $56 \mathrm{kp}$ pracownikowi przysługuje, co prawda, roszczenie o przywrócenie do pracy, ale z ograniczeniami wynikającymi z zastosowania $₫ 2$ art. $45 \mathrm{w}$ związku z art. $56 \S 2$. W odniesieniu do pracowników zatrudnionych na podstawie umowy o pracę na czas określony to zgodnie z art. $59 \mathrm{kp} \mathrm{w}$ razie rozwiązania przez pracodawcę takiej umowy z naruszeniem przepisów o rozwiązywaniu umów o pracę bez wypowiedzenia pracownikowi przysługuje wyłącznie odszkodowanie, jeżeli upłynął już termin, do którego umowa miała trwać, lub gdy przywrócenie do pracy byłoby niewskazane ze względu na krótki okres, jaki pozostał do upływu tego terminu. Odszkodowanie przysługuje w wysokości określonej w art. 58, to jest w wysokości wynagrodzenia za czas, do którego umowa miała trwać, nie więcej jednak niż za okres wypowiedzenia.

W świetle wprowadzonego limitu ustawowego, zgodnie z którym okres zatrudnienia na podstawie umowy o pracę na czas określony, a także łączny okres zatrudnienia na podstawie umów o pracę na czas określony zawieranych między tymi samymi stronami 
stosunku pracy, nie może przekraczać 33 miesięcy, a łączna liczba tych umów nie może przekraczać trzech, warto poddać pod rozwagę zasadność utrzymywania iluzorycznej, jak się wydaje, z uwagi na praktykę wymiaru sprawiedliwości możliwości restytucji stosunku pracy pracowników, z którymi pracodawca rozwiązał umowę o pracę zawartą na czas określony. Jak wiadomo, jedynie w wyjątkowych sytuacjach ustawodawca dopuścił możliwość dłuższego niż 33-miesięczny okresu obowiązywania umowy o pracę na czas określony.

Wobec powyższego można mieć uzasadnione obawy, iż obecnie w zdecydowanej większości przypadków będziemy mieli do czynienia z sytuacją, w której w momencie orzekania przez sąd pracy w przedmiocie wadliwości rozwiązania umowy o pracę termin, do końca którego umowa ta miała trwać, już dawno upłynie lub też przywrócenie do pracy będzie niewskazane ze względu na krótki okres, jaki pozostał do końca tego terminu (art. $59 \mathrm{kp}$ ). Wówczas pracownikowi pozostanie jedynie odszkodowanie w wysokości wynagrodzenia za czas, do którego upływu umowa miała trwać, nie więcej jednak niż za okres wypowiedzenia.

Różnicowanie sytuacji prawnej pracowników w przepisach prawa pracy jest oczywiście dopuszczalne, gdyż zakres wolności pracy pracownika powinien być współkształtowany przez ochronę wolności pracodawców, w tym wolności prowadzenia działalności gospodarczej $^{14}$, nie powinno się to jednak odbywać bez pogłębionej refleksji ustawodawcy.

\section{Charakter prawny odszkodowania z tytułu wadliwego wypowiedzenia lub rozwiązania umowy o pracę na czas określony}

Tym, co od wielu lat zajmuje orzecznictwo i doktrynę prawa pracy, jest odpowiedź na pytanie, czy odpowiedzialność pracodawcy z tytułu wadliwego wypowiedzenia lub rozwiązania umowy o pracę ma charakter kontraktowy, czy deliktowy. Zajmując się od lat prawem pracy, studiując wnikliwie wypowiedzi doktryny i judykatury, muszę stwierdzić, że konstatacja o kontraktowym charakterze tej odpowiedzialności jeszcze do jakiegoś czasu wydawała się oczywista ${ }^{15}$. Po głębszym namyśle i rozważeniu przedstawionej w doktrynie argumentacji wydaje się jednak, że pogląd stanowiący o tym, iż wadliwe wypowiedzenie umowy lub jej rozwiązanie jest deliktem wadliwego aktu władzy publicznej, bezprawnie pozbawiającym pracownika dobra w postaci wolności pracy, nie jest wcale pozbawiony słuszności. Pracodawca, decydując o prawach publicznych pracownika, występuje wówczas jako organ dokonujący rozstrzygnięcia w sprawie indywidualnej. Wina nie jest więc przesłanką tej odpowiedzialności, gdyż podmioty, które wykonują władzę publiczną, odpowiadają na podstawie art. $417 \mathrm{kc}, \mathrm{z}$ tym jednak ograniczeniem, iż w zakresie bezprawnych aktów pracodawcy odpowiedzialność poniesie on sam, a nie Skarb Państwa.

14 A. Sobczyk, Wolność pracy..., s. 181.

15 Tamże, s 167 i n. oraz cytowana tam literatura. 
Przepisy Kodeksu pracy są w powyższym zakresie regulacjami szczególnymi dotyczącymi wykonywania władzy publicznej, o których mowa w art. $421 \mathrm{kc}^{16}$.

$\mathrm{W}$ związku z powyższym nie powinno dziwić, iż zgodnie $\mathrm{z}$ art. $44 \mathrm{kp}$ pracownik może „wnieść odwołanie” od wypowiedzenia umowy o pracę do sądu pracy, o którym mowa w dziale dwunastym. Bierność pracownika w tym zakresie powoduje, iż czynność pracodawcy, choć wadliwa, będzie prawnie skuteczna. Wypowiedzenie umowy o pracę, nawet sprzeczne $\mathrm{z}$ prawem lub nieuzasadnione, nie jest bowiem nieważne $\mathrm{z}$ mocy prawa ${ }^{17}$. W literaturze przedmiotu zwraca się uwagę, iż koncepcja czynności wadliwych, ale skutecznych, jest bez wątpienia korzystna dla pracownika $z$ uwagi na szybkie otwarcie dostępu do pomocy publicznej dla osoby, która utraciła pracę ${ }^{18}$.

Odszkodowanie przysługujące pracownikowi z tytułu wypowiedzenia lub rozwiązania przez pracodawcę umowy o pracę bez wypowiedzenia wbrew swojej nazwie nie stanowi odszkodowania w znaczeniu cywilistycznym, to jest świadczenia zmierzającego do wyrównania pracownikowi szkody majątkowej z tego tytułu.

Dla nabycia prawa do odszkodowania, o którym mowa w oddziałach 4 i 6 rozdziału II Kodeksu pracy, wystarczające jest wykazanie przez pracownika, iż do rozwiązania z nim umowy za wypowiedzeniem lub bez wypowiedzenia doszło „z naruszeniem przepisów”. Wysokość odszkodowania, która jest ustawowo limitowana, oderwana jest więc od szkody rzeczywiście przez pracownika poniesionej. Jest to świadczenie zryczałtowane, którego przyznanie nie wymaga wykazania przez pracownika ani szkody w znaczeniu damnum emergens ani lucrum cesans. Warto zwrócić uwagę, iż przynajmniej w jednym przypadku mechanizm odszkodowawczy został uregulowany właściwie. Mam tu na myśli umowę o pracę na okres próbny. Zgodnie z art. $50 \$ 1 \mathrm{kp}$, jeżeli wypowiedzenie umowy o pracę zawartej na okres próbny nastąpiło z naruszeniem przepisów o wypowiadaniu tych umów, pracownikowi przysługuje wyłącznie odszkodowanie. Odszkodowanie przysługuje w wysokości wynagrodzenia za czas, do którego upływu umowa miała trwać.

W doktrynie prawa pracy w zasadzie od początku obowiązywania analizowanych regulacji snuto rozważania na temat charakteru prawnego tegoż odszkodowania, wskazując na jego kompensacyjny charakter. Kompensacją zaś miała być objęta zarówno szkoda majątkowa, jak i niemajątkowa (krzywda) ${ }^{19}$.

Wskazuje się również na funkcję socjalną (alimentacyjną) odszkodowania, w znaczeniu zapewnienia pracownikowi określonych środków utrzymania w początkowym okresie po utracie zatrudnienia. Patrząc jednak na to świadczenie przez pryzmat praktyki wymiaru sprawiedliwości, kiedy to na prawomocny wyrok zasądzający pracownik czeka kilkadziesiąt miesięcy, można prowadzić jedynie teoretyczne wywody o funkcji socjalnej odszkodowania.

16 Tamże, s. 179.

17 Wyrok Sądu Najwyższego z dnia 16 maja 1997 r. I PKN 170/97, OSNP 1998/8/239.

18 Szerzej na ten temat A. Sobczyk, Wolność pracy..., s. 169 i n.

19 Zob. T. Zieliński, Prawo pracy. Zarys systemu, cz. II, Prawo stosunku pracy, Warszawa-Kraków 1986, s. 92. 
Wydaje się jednak, iż odszkodowanie regulowane przepisami kodeksu pracy ma w przeważającej mierze charakter kary cywilnej, jaką sąd pracy nakłada na pracodawcę z tytułu naruszenia przepisów o rozwiązywaniu umów. W tym znaczeniu odszkodowanie powinno spełnić funkcję represyjną oraz prewencyjną. Żeby jednak tak rzeczywiście się stało, jego wysokość powinna być zwiększona, zwłaszcza w odniesieniu do wadliwego rozwiązania umowy o pracę bez wypowiedzenia. De lege lata paradoksalnie surowsza sankcja grozi za wadliwe wypowiedzenie umowy o pracę, które z oczywistych względów jest dla pracownika mniej dolegliwe, niż z tytułu wadliwego rozwiązania umowy o pracę bez wypowiedzenia ${ }^{20}$.

Co więcej, w sytuacjach, w których odszkodowanie występuje jako świadczenie alternatywne do przywrócenia do pracy, wybór tego drugiego roszczenia powodowałby zanik funkcji represyjno-prewencyjnej, chyba że uznamy, iż powrót zwolnionego pracownika na dotychczasowe stanowisko jest dla pracodawcy dostateczną dolegliwością.

Niemniej tak ukształtowany model dochodzenia roszczeń z tytułu wadliwego wypowiedzenia lub rozwiązania umowy bez wypowiedzenia skutkuje tym, że ani pracownik nie otrzymuje stosownej kompensaty poniesionej szkody (majątkowej i niemajątkowej), ani też pracodawca nie zostaje ukarany w stopniu, który mógłby na przyszłość powstrzymywać go od podobnych działań.

Dodatkowo warto zauważyć, iż w praktyce samo postępowanie sądowe zainicjowane przez pracownika odwołaniem się od wypowiedzenia czy rozwiązania umowy o pracę, $\mathrm{z}$ racji cechujących te sprawy rozbudowanych postępowań dowodowych, w ramach których dochodzi do przesłuchania wielu innych pracowników w charakterze świadków czy też zgromadzenia obszernego materiału dowodowego w postaci dokumentów, również (jeżeli nie przede wszystkim) stanowi wymierną stratę majątkową dla podmiotu zatrudniającego.

\section{Podsumowanie}

Na tle przedstawionych powyżej zagadnień w obecnie obowiązującej regulacji uprawnień pracowników zatrudnionych na podstawie umowy o pracę na czas określony w związku z wadliwym wypowiedzeniem lub rozwiązaniem umowy o pracę rysuje się wiele mankamentów. Trudno jest uznać środki ochrony stosunku pracy nawiązanego na podstawie umowy na czas określony, mające powszechne zastosowanie, za odpowiednie i dostateczne dla skutecznej realizacji funkcji ochronnej prawa pracy ${ }^{21}$.

20 Szerzej na ten temat M. Latos-Miłkowska, Odszkodowanie z tytułu wadliwego wypowiedzenia i rozwiązania umowy o prace - o potrzebie zmiany regulacji, Monitor Prawa Pracy 2016, 5, s. 239-242.

${ }_{21}$ Więcej na temat funkcji ochronnej prawa pracy zob. M. Skąpski, Ochronna funkcja prawa pracy w gospodarce rynkowej, Warszawa 2006, s. 105, 443 i n.; B.M. Ćwiertniak, Z. Salwa, Z. Góral, w: K.W. Baran (red.), Zarys systemu prawa pracy, t. I, Część ogólna prawa pracy, Warszawa 2010, s. 167199, 665-666; A. Sobczyk, Prawo pracy w świetle konstytucji RP, t. I, Warszawa 2013, s. 4. 
Uzasadnione wydaje się wprowadzenie powszechnego obowiązku pracodawcy uzasadniania przyczyn wypowiedzenia zawartej na czas określony umowy o pracę w miejsce funkcjonującej obecnie ograniczonej kontroli sądowej zasadności wypowiedzenia wyłącznie w odniesieniu do kategorii pracowników wymienionych w $\$ 5$ art. $50 \mathrm{kp}$.

Podczas prac nad nowym kodeksem pracy powinno się również rozważyć, czy w obecnym kształcie zatrudnienia na podstawie umów o pracę na czas określony zasadne jest w ogóle utrzymywanie roszczenia o przywrócenie do pracy pracowników, którym w wadliwy sposób pracodawca wypowiedział lub rozwiązał umowę o pracę. W praktyce nie są odosobnione przypadki ponownego rozwiązania przez pracodawcę umowy o pracę z pracownikiem, podejmującym pracę $\mathrm{w}$ wyniku przywrócenia, $\mathrm{w}$ których pracodawcy w zasadzie nie można przypisać złej woli w takim postępowaniu. Mam tu na myśli na przykład sytuację obiektywnego braku pracy dla zwalnianego pracownika czy też pozostającą w mocy i aktualną przyczynę poprzedniej decyzji pracodawcy, która w połączeniu $\mathrm{z}$ uchybieniem czysto formalnym stała się podstawą przywrócenia do pracy. Wydaje się, iż w tym pierwszym przypadku jest to skutek mankamentu obecnej regulacji polegający na tym, iż uznając racje pracownika, sąd pracy może go przywrócić nie tyle „do pracy”, ile „do pracy na poprzednich warunkach”. Przywrócenie na poprzednich warunkach oznacza, iż pracodawca jest obowiązany zatrudnić pracownika na takim samym stanowisku, jakie zajmował poprzednio, zapewnić mu możliwość wykonywania takiej samej pracy. Przywracając pracownika do pracy na poprzednich warunkach, sąd pracy, wbrew woli pracodawcy, ingeruje w swobodę prowadzenia działalności gospodarczej pracodawcy.

Gdyby jednak ustawodawca zdecydował się na pozostawienie możliwości przywrócenia do pracy pracownika, którego z pracodawcą łączyła umowa o pracę zawarta na czas określony, to zasadne jest zwrócenie uwagi na postulaty doktryny prawa pracy zmierzające do stworzenia możliwości przywrócenia pracownika do pracy na takich warunkach, w których istnieć będzie realna, a nie iluzoryczna możliwość kontynuowania zatrudnienia $^{22}$. Jest to jeden z możliwych kierunków uczynienia instytucji przywrócenia do pracy bardziej efektywnej, choć i w takim kształcie nie będzie ona pozbawiona mankamentów. Więź prawna łącząca pracownika z pracodawcą powinna być oparta na wzajemnym zaufaniu i lojalności, o które może być trudno po długotrwałym i wyniszczającym obie strony postępowaniu sądowym.

Warto nadmienić, iż zagadnienie zasadności wprowadzenia do Kodeksu pracy odmiennego od obecnego modelu odpowiedzialności pracodawcy z tytułu prawnie wadliwego wypowiedzenia lub rozwiązania umowy o pracę zawartej na czas określony było już szeroko analizowane przez wybitnych przedstawicieli nauki prawa pracy na gruncie przygotowanego w 2005 r. projektu kodeksu pracy ${ }^{23}$.

22 Por. Z. Hajn, Ochrona trwałości stosunku pracy a flexicurity, w: G. Goździewicz (red.), Ochrona trwałości stosunku pracy w społecznej gospodarce rynkowej, Warszawa 2010, s. 91-92, A. Sobczyk, Prawo pracy..., s. 238.

23 B. Wagner, Niektóre elementy regulacji stosunku pracy w projekcie kodeksu pracy, Praca i Zabezpieczenie Społeczne 2008, 9, s. 8 i n.; W. Sanetra, Kilka uwag o projektowanych zmianach przepisów o wypowiedzeniu umowy o pracę, Gdańskie Studia Prawnicze 2007, XVII, Księga jubileuszowa poświęcona 
Wśród zaproponowanych tam rozwiązań szczególnie interesująca wydaje się propozycja legislacyjna uprawniająca pracodawcę do zwolnienia się z obowiązku przywrócenia pracownika do pracy w zamian za zapłatę znacznie wyższego niż obecnie (bo 9-krotnego) wynagrodzenia za pracę.

Wydaje się, iż podczas podjętych na nowo prac kodyfikacyjnych powinno się powrócić do kwestii podstaw prawnych i granic odpowiedzialności pracodawcy z tytułu wadliwego wypowiedzenia lub rozwiązania umowy o pracę zawartej na czas określony. Zagadnienie to bez wątpienia zasługuje na kompleksową, spójną i skuteczną regulację.

Pomimo powszechnie uznawanej za dopuszczalną tzw. uzupełniającej, bo opartej na przepisach Kodeksu cywilnego, odpowiedzialności odszkodowawczej pracodawcy warto rozważyć wprowadzenie do Kodeksu pracy takiej regulacji, która będzie gwarantowała pracownikom bardziej realne zaspokojenie poniesionej szkody, stanowiąc jednocześnie dla pracodawcy odczuwalną dolegliwość w przypadkach zupełnej arbitralności podjętej decyzji czy też oparcia jej na niedozwolonych prawnie podstawach różnicowania pracowników ${ }^{24}$.

Nie należy bowiem całkowicie, tak jak ma to miejsce obecnie, tracić z pola widzenia usprawiedliwionego interesu prawnego i gospodarczego pracodawcy, który jest również chroniony przez określone wartości konstytucyjne. Innymi słowy, zakres wolności pracy pracownika powinien być współkształtowany z uwzględnieniem ochrony prawa własności pracodawców oraz swobody prowadzenia działalności gospodarczej.

W zakresie ochrony prawnej przysługującej stronom stosunku pracy w związku z rozwiązaniem umowy o pracę z mocy jednostronnej czynności prawnej zauważalna jest znacząca nierówność. Szczególnie widoczna jest ona w przypadku wypowiedzenia umowy o pracę dokonanego przez pracownika. Kodeks pracy nie przewiduje dla pracodawcy żadnych roszczeń $z$ tego tytułu. Ochrona prawna przewidziana dla pracodawcy w przypadku rozwiązania umowy o pracę przez pracownika bez wypowiedzenia jest jedynie ograniczona do przypadku „nieuzasadnionego rozwiązania umowy o pracę”, a więc wyłącznie gdy przyczyną wskazaną przez pracownika jest ciężkie naruszenie podstawowych obowiązków względem pracownika (art. $55 \$ 1^{1} \mathrm{kp}$ ). Wysokość odszkodowania, jakiej może dochodzić pracodawca w przypadku rozwiązania umowy o pracę zawartej na czas określony, stanowi obecnie równowartość wynagrodzenia za czas, do którego upływu umowa miała trwać, nie więcej jednak niż za okres wypowiedzenia (art.

Prof. Urszuli Jackowiak, s. 209 i n.; M. Seweryński, Ochrona pracowników przed rozwiązaniem umowy o pracę według projektu kodeksu pracy, w: Ochrona trwałości stosunku pracy w społecznej gospodarce rynkowej, G. Goździewicz (red.), Warszawa 2010.

24 Na potrzebę regulacji odpowiedzialności odszkodowawczej pracodawcy na zasadzie pełnej odpowiedzialności pracodawcy za szkodę wyrządzoną pracownikowi, tak jak to przewiduje art. $361 \mathrm{kc}$, już w 2009 r. zwracała uwagę T. Liszcz. Zob. T. Liszcz, Odpowiedzialność odszkodowawcza pracodawcy wobec pracownika, cz. II, Praca i Zabezpieczenie Społeczne 2008, 12 i Praca i Zabezpieczenie Społeczne 2009, 1, s. 2-10. Konieczność ustawowego podwyższenia wysokości odszkodowania z tytułu wadliwego wypowiedzenia lub rozwiązania umowy o pracę postuluje i obszernie uzasadnia M. Latos-Miłkowska, Odszkodowanie z tytułu..., s. 238-242. 
$61^{2} \mathrm{kp}$ ). W zasadzie należy stwierdzić, iż pracodawca, któremu pracownik nie postawił zarzutu ciężkiego naruszenia podstawowych obowiązków, a jedynie ustnie poinformował go o tym, iż nie zamierza ze skutkiem natychmiastowym kontynuować zatrudnienia, w świetle przepisów Kodeksu pracy pozbawiony został jakiejkolwiek ochrony prawnej.

Nie widzę uzasadnienia dla pozbawienia pracodawcy roszczenia odszkodowawczego na gruncie Kodeksu pracy w razie wadliwego rozwiązania przez pracownika umowy na czas określony. Podzielam również postulat, zgłoszony jeszcze w poprzednio obowiązującym stanie prawnym, obecnie tym bardziej uzasadniony, aby również pracownik był ustawowo obowiązany do wskazania przyczyny wypowiedzenia umowy o pracę na czas określony ${ }^{25}$.

\section{Bibliografia}

Cudowski B., Roszczenia z tytułu bezprawnego wypowiedzenia umowy o pracę na czas określony, Praca i Zabezpieczenie Społeczne 2011, 6.

Ćwiertniak B.M., Salwa Z., Góral Z., w: K.W. Baran (red.), Zarys systemu prawa pracy, t. I, Czesść ogólna prawa pracy, Warszawa 2010.

Gersdorf M., Otwarte drzwi dla odpowiedzialności cywilnej pracodawcy za wadliwe zwolnienie pracownika, Praca i Zabezpieczenie Społeczne 2008, 1.

Hajn Z., Ochrona trwałości stosunku pracy a flexicurity, w: G. Goździewicz (red.), Ochrona trwałości stosunku pracy w społecznej gospodarce rynkowej, Warszawa 2010.

Latos-Miłkowska M., Odszkodowanie z tytułu wadliwego wypowiedzenia i rozwiązania umowy o prace - o potrzebie zmiany regulacji, Monitor Prawa Pracy 2016, 5.

Liszcz T., Odpowiedzialność odszkodowawcza pracodawcy wobec pracownika, cz. II, Praca i Zabezpieczenie Społeczne 2008, 12 i Praca i Zabezpieczenie Społeczne 2009, 1.

Pisarczyk Ł., Odszkodowanie z tytułu wadliwego wypowiedzenia lub rozwiazania umowy o prace przez pracodawce, Praca i Zabezpieczenie Społeczne 2002, 8.

Sanetra W., Kilka uwag o projektowanych zmianach przepisów o wypowiedzeniu umowy o prace, Gdańskie Studia Prawnicze 2007, XVII, Księga jubileuszowa poświęcona Prof. Urszuli Jackowiak.

Sanetra W., Odszkodowanie „cywilne” za wadliwe rozwiązanie umowy o prace - czyli o pogladach nadal godnych uwagi, w: Z. Niedbała, M. Skąpski (red.), Problemy zatrudnienia we współczesnym ustroju pracy. Księga jubileuszowa na 55-lecie pracy naukowej i dydaktycznej Profesora Włodzimierza Piotrowskiego, Poznań 2008.

Seweryński M., Ochrona pracowników przed rozwiązaniem umowy o prace według projektu kodeksu pracy, w: Ochrona trwałości stosunku pracy w społecznej gospodarce rynkowej, G. Goździewicz (red.), Warszawa 2010.

Skąpski M., Ochronna funkcja prawa pracy w gospodarce rynkowej, Warszawa 2006.

Sobczyk A., Prawo pracy w świetle konstytucji RP, t. I, Warszawa 2013.

25 Zob. zdanie odrębne Sędziego Trybunału Konstytucyjnego Teresy Liszcz do wyroku Trybunału Konstytucyjnego z dnia 2 grudnia 2008 r., sygn. akt P 48/07 OTK-A 2008/10/173. 
Sobczyk A., Niewłaściwe ustanie stosunku pracy, Praca i Zabezpieczenie Społeczne 2014, 1. Sobczyk A., Wolność pracy i władza, Warszawa 2015.

Wagner B., Niektóre elementy regulacji stosunku pracy w projekcie kodeksu pracy, Praca i Zabezpieczenie Społeczne 2008, 9.

Zieliński T., Prawo pracy. Zarys systemu, cz. II, Prawo stosunku pracy, Warszawa-Kraków 1986. 